\title{
RESEARCH ON CORPUS OF LEARNERS OF SPANISH AS A FOREIGN
} LANGUAGE

\author{
Mónica Belda Torrijos ${ }^{1 *}$ \\ *lSpain Doctora en Filología Hispánica Polytecnic University of Valencia monica.belda.torrijos@ gmail.com \\ tel.: +34647008820
}

*Corresponding Author: -

Email: monica.belda.torrijos@gmail.com

\begin{abstract}
: -
The present article bridges the acquisition of second languages and corpus linguistics. The creation of a corpus for the analysis of the use of Spanish by foreigners is a central part of the research of Spanish as a foreign language. If we compare the investigations of corpus compilations written in Spanish with the compilations in English, we will observe that they are not so numerous. However, in recent years, a new interest has appeared and there is a substantial amount of written and oral information about Spanish as a foreign language.
\end{abstract}

Keywords: - Corpus; Spanish for foreigners; database.

\section{(ㄷ) (\$) (1)}




\section{RESUMEN}

El presente artículo tiende un puente entre la adquisición de segundas lenguas y la lingüística de corpus. La creación de un corpus para el análisis del uso del español por parte de extranjeros es una parte central en las investigaciones del español como lengua extranjera.

Si comparamos las investigaciones de recopilación de corpus escritos de español con las recopilaciones de inglés, observaremos que no son tan numerosas. No obstante, en estos últimos años, aparece un nuevo interés y hay una ingente cantidad de datos escritos y orales sobre el español como lengua extranjera.

Palabras clave: Corpus; español para extranjeros; base de datos.

\section{RESEARCH ON CORPUS OF LEARNERS OF SPANISH AS A FOREIGN LANGUAGE}

There are several corpus of General Spanish (L1 corpus):

- The Corpus of Current Spanish (CEA) has 540 million words and is labeled with morphological and/or categorical information (Subirats and Ortega, 2012).
- ROYAL SPANISH ACADEMY:
Database
(CORDE)

[online]. Diachronic Corpus of Spanish.

- ROYAL SPANISH ACADEMY: Database (CREA) [online]. Reference

Corpus of the current Spanish. Interactive query of a database with more than 200 million Spanish words.
- ROYAL
SPANISH
ACADEMY:
Database
(CORPES
$\mathrm{XXI}$ )

[online]. Corpus of the 21 st century Spanish. Interactive consultation of a database with more than 200 million Spanish words comprising written and oral texts from Spain, America, the Philippines and Equatorial Guinea, with a distribution of 25 million forms for each of the years included in the period 2001 to 2012.

- Spanish corpus: Corpus with 100 million words, developed by Professor Mark Davies, of Brigham Young University.

Cervantes Institute. Database (CAES) It comprises almost 575.000 linguistic elements, with a distribution that attends levels from $\mathrm{A} 1$ to $\mathrm{C} 1$ of the Common European Framework of Reference for Languages, applied to Spanish in the Curriculum Plan of the Cervantes Institute and L1 languages : Arabic, Mandarin Chinese, French, English, Portuguese and Russian. It has been built by collecting samples at various Cervantes Institute centers and universities from a wide number of countries, from October 2011 to September 2013.

Some researchers have collected compositions of language learners in order to study their mistakes, for example Fernández López (1990), Santos Gargallo (1991) and Vázquez (1991). According to Mendikoetxea, (2013: 15) these corpus are focused towards pedagogy. The corpus for error analysis for learners of Spanish as a Foreign Language (CORANE) is a collection of more than one thousand written texts and distributed on CD (Cestero Mancera and Penadés, 2009). More recently, we have the corpus The Anglia Polytechnic University Learner Spanish Corpus (Ife, 2004), the corpus of Taiwanese learners of Spanish (CATE, Lu, 2010) and a Spanish corpus of Italian learners (SCIL, Bailini, 2013). The written corpus of Spanish (CEDEL2; Lozano, 2009; Mendikoetxea, 2013) stands out in terms of scientific rigor and size (around 750,000 words). Data from this corpus were used for the acquisition of pronominal subjects and placements. The written data were used to study the acquisition of the copulative verb to be (ser o estar). The copulative verb is an area of great difficulty for learners of Spanish as a second language. Geeslin (2000) researched the linguistic aspects that affect the choice of the copulative verb in SLA, using data obtained in semi-structured interviews, an image description task and a contextualized questionnaire. A similar approach was followed by Cheng, Lu, and Giannakouros (2008) in their analysis of the semantics, pragmatics and lexical features of the use of the copulative verb in free compositions with data from the CATE corpus, mentioned above. One of the main results was to observe the choice of the copulative verb to be. It was concluded that learners choose the verb meaning "estar" when doing a descriptive writing and the verb meaning "ser" in narrative writing. The results of this research suggest that the use of forms that correspond to the meanings of to be: "ser" and "estar" must be subject not only to the linguistic variables but to different factors, the type of text and its size. This approach was adapted by Collentine and Asencion-Delaney (2010) in an analysis of how the type of discourse influences the choice of the copulative verb in L2. The compilation of corpus written in Spanish also presents the hierarchy of difficulties that students encounter when learning Spanish. Difficulties that refer to the complex system of Spanish, coordinated sentences, subordinate sentences, indicative/subjunctive modes, past perfect/imperfect, as well as difficulties encountered in equivalences that do not correspond in both languages.

Ortega (2000) uses an intermediate-level L2 Spanish corpus to investigate how to measure the syntactic complexity of a sentence in Spanish. He considers that the best predictors of syntactic complexity in his analysis were the clause lengt, the amount of subordination and the sentences production (Ortega, 2003).

Finally, Asencion-Delaney and Collentine (2011) also present a multidimensional analysis of an L2 Spanish corpus and observe how the Spanish learners of second and third year of University combine lexical aspects, grammatical aspects and syntactic structures to generate different discourses in what can be considered a first attempt to characterize the L2 learner's discourse, using a type of analysis which has been used for corpora in English (Biber et al., 2006). The corpus contains written compositions: letters, descriptions, summaries and argumentative compositions in order to be evaluated. A multidimensional analysis combines qualitative and quantitative research, technological tools, exploratory factor analysis and qualitative analysis of texts. This analysis reveals four important groups extracted from the corpus analysis based on the research of Spanish as a second language. Different types of speech are considered, characterized by two main stylistic 
variations: narration (with a concentration of verbal functions) and exposition (with a concentration of nominal characteristics), which provides information on how communication occurs in L2 discourse.

The Spanish Learner Language Oral Corpora (SPLLOC) is the most widely available resource for oral data. These crosssectional data banks were collected at the University of Southampton. Speech samples were obtained from native English speakers, from the beginner to the advanced levels. Students had to perform a description task and a writing task, among others (Mitchell et al., 2008). The creation of an L2 Spanish oral production database in the SPLLOC program is a milestone in the research on the acquisition of Spanish as L2. Data have been collected from students of Spanish in a formal instructional environment, among students of different levels (A1, A2, B1, B2, C1, C2). Both sound files and their transcriptions are available through the SPLLOC website. SPLLOC designers focus on oral data, rather than on written data, under the hypothesis that spontaneous speech produced in face-to-face interaction is more likely to provide a direct evidence on the L2 learner's interlanguage, thus minimizing the effects of self-correction and monitoring. Given the variability of students' oral production data and the tendency to avoid complex speech structures, SPLLOC's design encompasses a variety of genres (narrative, interview, image descriptions and peer-topeer discussions). There is also a substantial sample of each participant's speech (40-60 minutes), with different interlocutors, and a balance of open or closed tasks, in which the use of certain syntactic structures is expected (Mitchell et al., 2008 ).

Research in the oral production of Spanish often involves case studies or a small number of students, taking into account the difficulties of obtaining and transcribing the data. Campillos Llanos (2012: 23-26) offers a detailed account of the studies based on the analysis of interlanguage errors in oral compositions in Spanish. It presents an oral corpus that contains interviews to 40 students of different linguistic origin and different level of competence. This corpus has been transcribed and errors have been labeled as: phonetic errors, lexical errors, grammatical errors and pragmatic errors. The only multimodal corpus belongs to the University of Texas 'Spanish Proficiency Level Training' project, which has been developed to train teachers to evaluate the proficiency levels of Spanish learners' oral production (Koike, 2007).

A series of studies based on oral production aimed to investigate aspects such as the omitted subject, reflexives, concordances, word order, among others, which are the reflection of the parametric differences between Spanish and other languages, especially English. The longitudinal data of oral production in Spanish as L2 are scarce. In the 'Beyond Parameters' project at the University of Ottawa, some studies were carried out using longitudinal and transverse oral data (Muñoz Liceras et al., 1997). Other results were obtained by Díaz (2007), who interviewed students from different L1 origins (German, Swedish, Icelandic, Korean and Chinese).

\section{Bibliography}

[1].Asención-Delaney, Y, y Collentine, J. (2011). “A Multidimensional Analysis of a Written L2 Spanish Corpus." Applied Linguistics, 32(3), pp. 299-322.

[2].Bailini, S. (2013). SCIL: A Spanish Corpus of Italian Learners, Procedia. Social and Behavioral Sciences 95, pp. 5429.

[3].Biber, D, Davies, M, Jones,J. y Tracy-Ventura, N. (2006). Spoken and Written Register Variation in Spanish: A Multidimensional Analysis. Corpora, 1(1), pp. 1-37. Campillos Llanos, L. (2012). La expresión oral en español lengua extranjera:

[4].interlengua y análisis de errores basado en corpus. Unpublished PhD thesis. Madrid: Universidad Autónoma de Madrid.

[5].Cestero Mancera, A.M. y. Penadés, I. (2009). Corpus de textos escritos para el análisis de errores de aprendices de E/LE (CORANE). CD-ROM. Alcalá de Henares: Universidad de Alcalá.

[6].Collentine, J., y Asención-Delaney. J. (2010). A Corpus-based Analysis of the Discourse Functions of Ser/Estar+adjective in Three Levels of Spanish FL learners. Language Learning, 60(2), pp. 409-445.

[7].Cheng, A.Ch., Lu, H, Ch. y Giannakouros, P. (2008). The Uses of Spanish Copulas by Chinese-speaking Learners in a Free Writing Task. Bilingualism: Language and Cognition, 11, pp. 301-317.

[8]. Díaz, Lourdes. (2007). Interlengua Española: Estudio de Casos. Barcelona: Printulibro Intergrup.

[9]. Fernández López, S. (1990). Análisis de errores e interlengua en el aprendizaje del español como lengua extranjera. Tesis Doctoral. Madrid: Universidad Complutense de Madrid.

[10]. Geeslin, K. (2000). A New Approach to the Second Language Acquisition of Copula Choice in Spanish. En Spanish Applied Linguistics at the Turn of the Millennium: Papers from the 1999 Conference on the L1 \& L2 Acquisition of

[11]. Spanish and Portuguese, editado por Ronald P. Leow and Cristina Sanz, pp.50- 66. Somerville, MA: Cascadilla Press.

[12]. Ife, A. 2004. The L2 learner corpus: reviewing its potential for the early stages of learning en M. Baynham, A. Deignan and G. White (eds). Applied Linguistics at the Interface, pp. 91-103. London: Equinox.

[13]. Koike, D. (2007). Spanish Learner Corpus and Exercises. Austin, Texas: University of Texas.

[14]. Lozano, C. (2009). CEDEL2: Corpus Escrito del Español como L2 en C.M. Bretones, J.F. Fernández, J.R. Ibáñez, Ma .E. García, Ma .E. Cortés, S. Salaberri, Ma .S. Cruz, N. Perdú y B. Cantizano (eds) Applied Linguistics Now: Understanding Language and Mind/La Lingüística Aplicada actual: Comprendiendo el Lenguaje y la Mente, pp. 197-212. Almería: Universidad de Almería.

[15]. Lozano, C. y A. Mendikoetxea. (2013). Learner corpora and second language acquisition: the design and collection of CEDEL2 en A. Díaz-Negrillo, N. Ballier and P. Thompson (eds) Automatic Treatment and Analysis of Learner Corpus Data, pp. 65-100. Amsterdam: John Benjamins.

[16]. Lu, H. (2010). An annotated Taiwanese Learners. Corpus of Spanish, CATE, Corpus Linguistics and Linguistic Theory 6 (2), pp. 297-300. 
[17]. Mendikoetxea, A. (2013). 'Corpus-based research in second language Spanish' en K.L. Geeslin (ed.) The Handbook of Spanish Second Language Acquisition, pp. 11-29. Hoboken, New Jersey: Blackwell/John Wiley.

[18]. Mitchell, R., L. Domínguez, M.J. Arche, F. Myles and E. Marsden. (2008). 'SPLLOC: a new database for Spanish second language acquisition research' in L. Roberts, F. Myles and A. David (eds) EuroSLA Yearbook 8, pp. 287304. Amsterdam and Philadelphia: John Benjamins.

[19]. Muñoz Liceras, Maxwell, J. D., Laguardia, B., Fernández, Z., Fernández, R. y Díaz, L. (1997). A longitudinal study of Spanish non-native grammars: beyond parameters in A.T. Pérez-Leroux and W.R. Glass (eds.) Contemporary Perspectives on the Acquisition of Spanish, pp. 99-132. (Volumen 1:Developing Grammars.) Somerville, Massachusetts: Cascadilla Press.

[20]. Ortega, L. (2000). Understanding Syntactic Complexity: The Measurement of Change in the Syntax of Instructed L2 Spanish Learners. Tesis Doctoral Inédita, University of Hawaii at Manoa.

[21]. Santos Gargallo, I. (1991). La enseñanza de segundas lenguas. Análisis de errores en la expresión escrita de estudiantes de español cuya lengua nativa es el serbo-croata.

[22]. Tesis Doctoral. Madrid: Universidad Complutense.

[23]. Vázquez, G. (1991). Análisis de errores y aprendizaje de español/lengua extranjera. Frankfurt: Peter Lang.

\section{WEBOGRAPHY}

Davies, Mark. (2002). Corpus del Español: 100 million words, 1200s-1900s.

Recuperado de:http://www.corpusdelespanol.org.

REAL ACADEMIA ESPAÑOLA: Banco de datos (CORDE) [en línea]. Corpus diacrónico del español. Recuperado de: http://www.rae.es

REAL ACADEMIA ESPAÑOLA: Banco de datos (CREA) [en línea]. Corpus de

referencia del español actual. Recuperado de: http://www.rae.es/

REAL ACADEMIA ESPAÑOLA: Banco de datos (CORPES XXI) [en línea]. Corpus

del español del siglo XXI. Recuperado de: http://www.rae.es/

Subirats, C y Ortega, M. (2012). Corpus del español actual. Recuperado de:

http://sfncorpora.uab.es/CQPweb/cea/ 